Article

\title{
Anti-Influenza Virus Activity and Chemical Components from the Parasitic Plant Cuscuta japonica Choisy on Dimocarpus longans Lour.
}

\author{
Ju-Chien Cheng ${ }^{1,+}{ }^{,}$Chia-Ching Liaw ${ }^{2,3,+}+{ }^{+}$, Ming-Kuem Lin ${ }^{4} \mathbb{C}_{\text {, Chao-Jung Chen }}{ }^{5,6}$, \\ Chien-Liang Chao ${ }^{7}$, Chih-Hua Chao ${ }^{8} \mathbb{D}$, Yueh-Hsiung Kuo ${ }^{4,9,10} \mathbb{D}$, Yen-Po Chiu ${ }^{1}$, \\ Yu-Shin Peng ${ }^{1}$ and Hui-Chi Huang ${ }^{4,11, *(D)}$ \\ 1 Department of Medical Laboratory Science and Biotechnology, China Medical University, Taichung 404, \\ Taiwan; jccheng@mail.cmu.edu.tw (J.-C.C.); albert50137@gmail.com (Y.-P.C.); \\ sean56789912@gmail.com (Y.-S.P.) \\ 2 Division of Chinese Materia Medica Development, National Research Institute of Chinese Medicine, \\ Taipei 112, Taiwan; liawcc@nricm.edu.tw \\ 3 Department of Biochemical Science and Technology, National Chiayi University, Chiayi 60004, Taiwan \\ 4 Department of Chinese Pharmaceutical Sciences and Chinese Medicine Resources, China Medical University, \\ Taichung 404, Taiwan; linmk@mail.cmu.edu.tw (M.-K.L.); kuoyh@mail.cmu.edu.tw (Y.-H.K.) \\ 5 Graduate Institute of Integrated Medicine, China Medical University, Taichung 404, Taiwan; \\ cjchen@mail.cmu.edu.tw \\ 6 Proteomics Core Laboratory, Department of Medical Research, China Medical University Hospital, \\ Taichung 404, Taiwan \\ 7 Sinphar Pharmaceutical Co., Ltd., Sinphar Group, Yilan 269, Taiwan; chaokmc@gmail.cmu.edu.tw \\ 8 School of Pharmacy, China Medical University, Taichung 404, Taiwan; chchao@mail.cmu.edu.tw \\ 9 Chinese Medicine Research Center, China Medical University, Taichung 404, Taiwan \\ 10 Department of Biotechnology, Asia University, Taichung 413, Taiwan \\ 11 Master Program for Food and Drug Safety, China Medical University, Taichung 404, Taiwan \\ * Correspondence: hchuang@mail.cmu.edu.tw; Tel.: +886-4-2205-3366 (ext. 5211) \\ + These authors contributed equally to this work.
}

Received: 14 August 2020; Accepted: 23 September 2020; Published: 26 September 2020

\begin{abstract}
Dodder (Cuscuta spp.) is a parasitic weed damaging many plants and agricultural production. The native obligate parasite Cuscuta japonica Choisy (Japanese dodder) parasitizes Dimocarpus longans Lour., Ficus septica Burm. F., Ficus microcarpa L.f., Mikania micrantha H.B.K. and Melia azedarach Linn, respectively. Five Japanese dodders growing on different plants exhibit slightly different metabolites and amounts which present different pharmacological effects. Among these plants, a significant antiviral activity against influenza A virus (IAV) was found in Japanese dodder parasitizing on D. longans Lour. (CL). To further explore methanol extract components in Japanese dodder (CL), four undescribed aromatic glycosides, cuscutasides A-D (compounds 1-4) were isolated, together with twenty-six known compounds 5-30. The chemical structures of 1-4 were elucidated using a combination of spectroscopic techniques. The eighteen isolated compounds were evaluated for antiviral activity against IAV activity. Among them, 1-monopalmitin (29) displayed potent activity against influenza A virus (A/WSN/1933(H1N1)) with $\mathrm{EC}_{50} 2.28 \pm 0.04 \mu \mathrm{M}$ and without noteworthy cytotoxicity in MDCK cells. The interrupt step of $\mathbf{2 9}$ on the IAV life cycle was determined. These data provide invaluable information for new applications for this otherwise harmful weed.
\end{abstract}

Keywords: Cuscuta japonica Choisy; Dimocarpus longans Lour.; parasitic plant; influenza A virus (IAV); cuscutasides 


\section{Introduction}

Influenza A virus (IAV) is a highly contagious, epidemic etiology respiratory illness that has affected 3-5 million population annually worldwide with high mortality and morbidity [1]. This virus has developed multiple strategies to evade host immune defenses including continuous genetic changes through mutation and re-assortment [2]. The influenza viral life-cycle is well known. The viral ion channel protein M2 and viral releasing neuraminidase are the clinical therapeutic targets present time. However, most currently circulating IAV's are resistant to M2 inhibitors, neuraminidase inhibitors are the only class of recommended anti-IAV treatments to date [3]. It is still unmet for anti-IAV agents. Plants have long been thought a potential source of anti-viral drugs. With the development of new influenza strains resistant to current commercially antiviral drugs, a wider range of influenza antiviral compounds is needed [4].

Cuscuta japonica Choisy (Japanese dodder) is a unique kind of holoparastic vine from the Convolvulaceae family. Dodder is completely dependent on the host plant for nourishment to survive, so its phytochemical constituents depend on the type of host [5]. When Cuscuta sp. parasitizes a medicinal plant such as Taxus brevifolia and grows thereon and can produce secondary metabolites lead to a pharmaceutical component (camptothecin) [6]. Dodder is a parasitic weed and spreads rapidly, afflicting many commercial crops, ornamentals and native plants by virtually decimating or killing them [7]. Herbicides are able to control the parasitic weed and are surely phytotoxic to the host plants. There are thus advantages in utilizing this harmful weed as a source of valuable products, including increased effective management and reduced negative impacts on the environment.

Cuscuta is a genus of about 170 species of threadlike, yellowish, orange or reddish parasitic plants distributed mainly in North and South America. A few species are found in Asia and Europe. The C. chinensis Lam., C. japonica Choisy, and Cuscutae Semen seeds are a well-known traditional medicinal material, commonly used for improving sexual function, tonifying the livers and kidneys, reducing urination, treating aches and weakness in the loins and knees, and treating pharyngitis [8]. Investigation into the phytochemistry of Cuscuta spp. seeds has so far led to the isolation of many compounds, consisting of flavonoids, alkaloids, steroids, fatty acids, lignans [7], aromatics [9], resin glycosides [10] and polysaccharides [7]. These compounds exhibit a range of pharmacological effects such as hepatoprotective, anti-osteoporotic, immune regulation, neuroprotection, antioxidative, anti-aging, cytotoxic, renoprotective, reproductive system, prevention of abortion, antimutagenic effect, antidiabetic, cardioprotective, antidepressant, and anti-inflammatory activities [7]. However, the parasitic plant $C$. japonica growing onto a plethora of different plants has only been the subject of rare studies concerning host-parasite relationships and phytochemical constituents. In this work we analyzed the chemical fingerprint in five Japanese dodders (C. japonica) parasitizing on different plants using HPLC, thus evidencing slight differences.

In the course of screening for anti-virus (H1N1) substances from five Japanese dodders parasitizing different plants (Dimocarpus longans Lour., Ficus septica Burm. F., Ficus microcarpa L. f., Mikania micrantha H. B. K. and Melia azedarach Linn., respectively), Japanese dodder parasitizing on D. longans Lour. (CL) exhibited significantly suppressed anti-virus activation. Japanese dodder (CL) was not previously studied from a phytochemical viewpoint. During research efforts to discover bioactive compounds from the methanol extract of the whole plant Japanese dodder (CL), four previously undescribed aromatic glycosides 1-4 and four known aromatic glycosides 5-8, two caffeoylquinic acid derivatives 9-10, five lignans 11-15, four tropane alkaloids 16-19, two indole alkaloids 20-21, five flavanoids 22-26, two aromatic compounds 27-28, and two fatty acids 29-30 were obtained. Eighteen of the isolated compounds were subjected to anti-IAV activity assays and the effective compound that interrupted the IAV life cycle was determined. 


\section{Results}

The chemical constituent patterns of five Japanese dodder parasitizing on different plants, D. longans Lour. (CL), F. septica Burm. F. (CF), F. microcarpa L. f. (CFM), M. micrantha H. B. K. (CM) and $M$. azedarach Linn. (CMA), respectively, detected by HPLC-DAD analyses were slightly different (Figure 1). The MeOH extract $(100 \mu \mathrm{g} / \mathrm{mL})$ of Japanese dodder parasitizing on D. longans Lour. (CL) showed anti-IAV activity with no cytotoxicity in Madin-Darby canine kidney (MDCK) cells (Figure 2a). Among them, the most active extract from Japanese dodder (CL) was further subjected to solvent partitioning and three layers were obtained, including ethyl acetate (CLE), $n$-butanol (CLB), and water layers (CLW). The CLE further showed stronger anti-IAV activity at $50 \mu \mathrm{g} / \mathrm{mL}$ without cytotoxicity against MDCK cells at $100 \mu \mathrm{g} / \mathrm{mL}$ (Figure 2b). To understand the source of the active compound in the CLE extract, we were isolated by employing diaion HP-20, Sephardex LH-20, silica gel, and $\mathrm{C}_{18}$ column chromatography and further purified by RP-HPLC to obtain 30 compounds, including four new compounds 1-4 (Figure 3) and twenty-six known compounds.

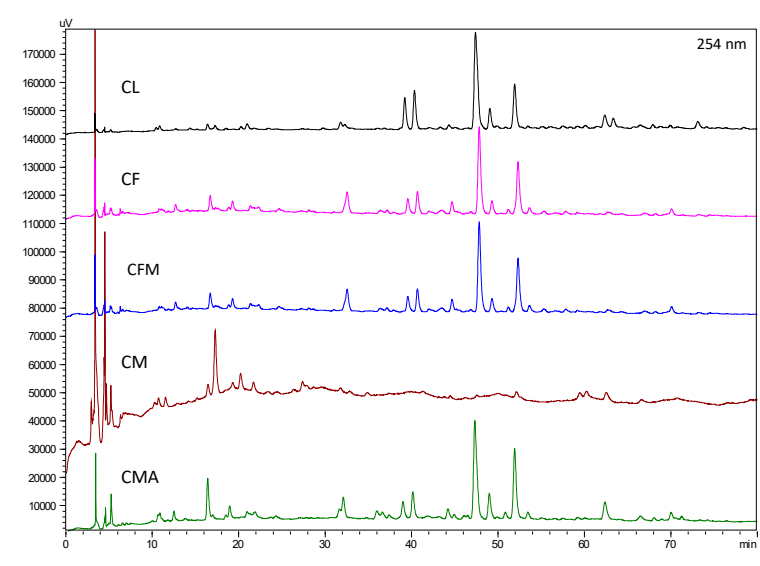

(a)

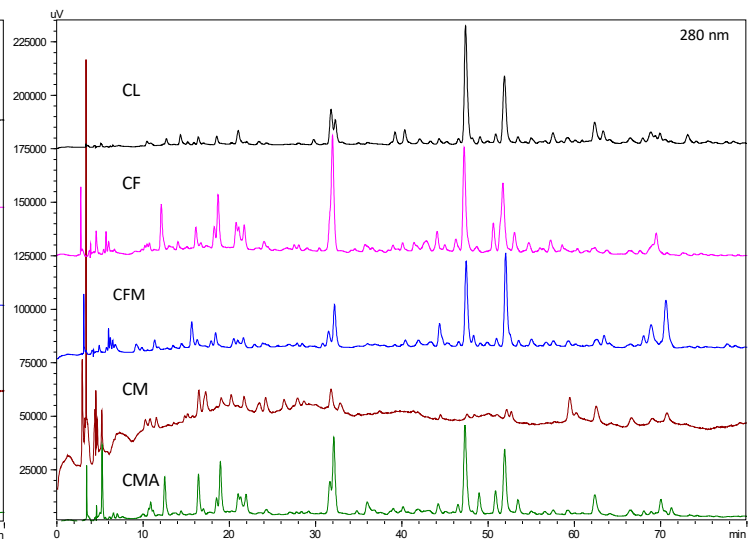

(b)

Figure 1. HPLC-DAD chromatogram of five Japanese dodder parasitizing on different plants, D. longans Lour. (CD), F. septica Burm. f. (CF), F. microcarpa L. f. (CFM), M. micrantha H. B. K. (CM), and M. azedarach Linn (CMA), respectively. Wavelengths: $254 \mathrm{~nm}$ (a) and 280 (b) $\mathrm{nm}$.

\subsection{Structural Elucidation of New Compounds}

Compound 1 was isolated as a white amorphous solid. Its molecular formula was deduced to be $\mathrm{C}_{21} \mathrm{H}_{22} \mathrm{O}_{10}$ from the analysis of its ${ }^{13} \mathrm{C}-\mathrm{NMR}$ spectrum and the HRESIMS molecular ion peak at $m / z 433.1123[\mathrm{M}-\mathrm{H}]^{-}$, calculated for 433.1129), corresponding to 11 degrees of unsaturation. The UV absorption maxima at $\lambda_{\max }$ of 207 and $309 \mathrm{~nm}$ implied the presence of a conjugated chromophore, while the IR spectrum exhibited absorption bands due to a hydroxyl $\left(3361 \mathrm{~cm}^{-1}\right)$, a conjugated carbonyl $\left(1693 \mathrm{~cm}^{-1}\right)$, and an 1,4-disubtituent aromatic ring $\left(1604,1514\right.$ and $\left.831 \mathrm{~cm}^{-1}\right)$. The ${ }^{1} \mathrm{H}-\mathrm{NMR}$ spectrum of 1 (Table 1) displayed downfield signals of 1,4-disubstitued aromatic protons at $\delta_{\mathrm{H}} 7.56(2 \mathrm{H}, \mathrm{d}$, $\left.J=8.5 \mathrm{~Hz}, \mathrm{H}-2^{\prime \prime} / 6^{\prime \prime}\right)$ and $6.79\left(2 \mathrm{H}, \mathrm{d}, J=8.5 \mathrm{~Hz}, \mathrm{H}-3^{\prime \prime} / 5^{\prime \prime}\right)$, and a pair of trans olefinic protons at $\delta_{\mathrm{H}} 7.60\left(1 \mathrm{H}, \mathrm{d}, J=16.0 \mathrm{~Hz}, \mathrm{H}-7^{\prime \prime}\right)$ and $6.37\left(1 \mathrm{H}, \mathrm{d}, J=16.0 \mathrm{~Hz}, \mathrm{H}-8^{\prime \prime}\right)$ for the trans $p$-coumaroyl moiety, along with an anomeric proton at $\delta_{\mathrm{H}} 5.05(1 \mathrm{H}, \mathrm{d}, J=7.5 \mathrm{~Hz}, \mathrm{H}-1)$ which resonances with one di-oxygenated carbon at $\delta_{C} 100.9$ for a sugar moiety. The ${ }^{13} \mathrm{C}-\mathrm{NMR}$ (Table 2) and DEPT spectra of 1 showed the obvious resonances for 10 carbons, which were resolved as four aromatic methine $C-2^{\prime \prime} / C-6^{\prime \prime}\left(\delta_{C} 131.5 \times 2\right)$ and $C-3^{\prime \prime} / C-5^{\prime \prime}\left(\delta_{C} 116.9 \times 2\right)$, two aromatic quaternary C- $1^{\prime \prime}\left(\delta_{C} 127.3\right)$ and $C-4^{\prime \prime}\left(\delta_{C} 161.5\right)$, two olefinic methine $C-7^{\prime \prime}\left(\delta_{C} 147.1\right)$ and $C-8^{\prime \prime}\left(\delta_{C} 114.9\right)$, one unsaturated carbonyl carbon $C-9^{\prime \prime}\left(\delta_{C} 169.1\right)$, and one anomeric carbon $C-1\left(\delta_{C} 100.9\right)$. These data suggested that 1 is a glycoside derivative with a para-coumaroyl moiety [11]. The correlation between $\mathrm{H}-1$ to $\mathrm{H}-6$ [ $\delta_{\mathrm{H}} 5.05$ (H-1), 3.46 (H-2), 3.48 (H-3), 3.37 (H-4), 3.77 (H-5), 4.23 and $\left.4.55\left(\mathrm{H}_{2}-6\right)\right]$ showed a coupling network 
in the ${ }^{1} \mathrm{H}^{-1} \mathrm{H}$ COSY spectrum, which proved the presence of the sugar unit to be a glucospyranoside (Figure 4). The $\beta$-configuration of glucopyranose was determined through NOESY correlations and coupling constant [12]. HMBC correlations between the H-6 and carbonyl carbon $\left(\delta_{C} 169.1, C-9^{\prime \prime}\right)$ indicated the presence of $p$-coumaroyl moiety at glucose methylene signal ( $\left.\delta_{C} 64.7, C-6\right)$. Apart from the above observation, further ${ }^{13} \mathrm{C}-\mathrm{NMR}$ spectrum analysis revealed the other signals for a carbonyl $\left(\delta_{C} 171.4\right)$, two quaternary carbons $\left(\delta_{C} 167.5\right.$ and 164.9$)$, two olefinics $\left(\delta_{C} 101.6\right.$ and 92.0$)$, and a methyl group $\left(\delta_{C} 19.8\right)$ carbons for this moiety. The additional signals were deduced from the resonances at $\delta_{\mathrm{H}} 6.09\left(1 \mathrm{H}, \mathrm{d}, J=1.0 \mathrm{~Hz}, \mathrm{H}-3^{\prime}\right), 5.72\left(1 \mathrm{H}, \mathrm{d}, J=1.0 \mathrm{~Hz}, \mathrm{H}-2^{\prime}\right)$ and $2.20\left(3 \mathrm{H}, \mathrm{s}, \mathrm{H}_{3}-5^{\prime}\right)$, which were supported by corresponding signals at $\delta_{\mathrm{C}} 101.6\left(\mathrm{C}-3^{\prime}\right), 92.0\left(\mathrm{C}-2^{\prime}\right)$ and $19.8\left(\mathrm{C}-5^{\prime}\right)$ in the HSQC spectrum. Combined with HMBC correlations, the moiety was established as 5-methyl-2-furoyl. The position of this 5-methyl-2-furoyl unit was assigned unambiguously as C-1 by HMBC correlation between the anomeric proton $\left(\delta_{\mathrm{H}} 5.05, \mathrm{H}-1\right)$ to the carbonyl $\left(\delta_{\mathrm{C}} 171.4, \mathrm{C}-6^{\prime}\right)$ (Figure 4$)$. Hence the structure of 1 was established as $6-O-(E)-p$-coumaroyl-1- $\beta$-O-(5-methyl-2-furoyl)- $\beta$-D-glycopyranoside, and the compound was given the trivial name cuscutaside $\mathrm{A}$.
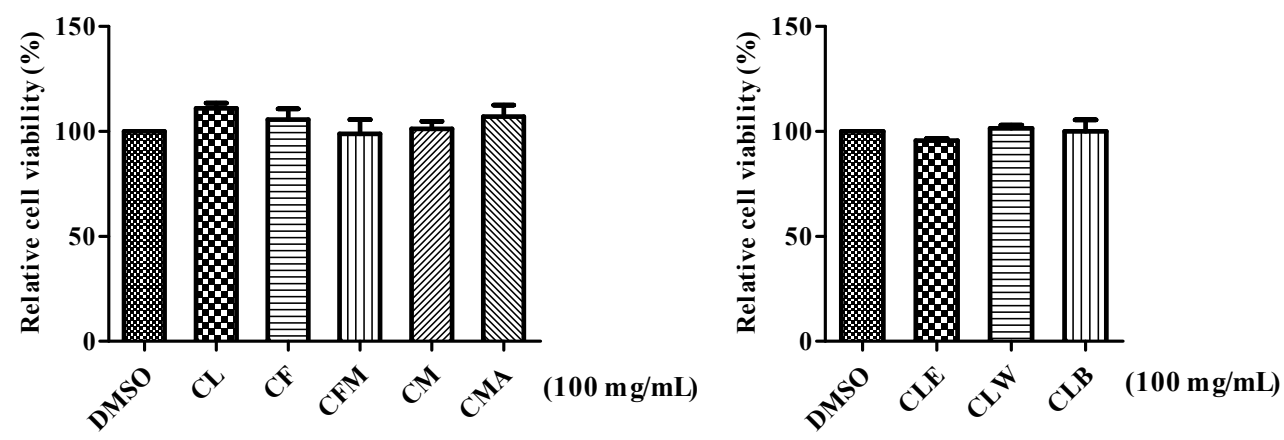

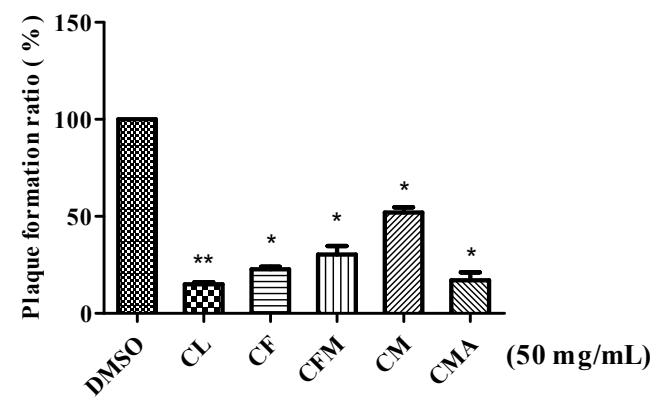

(a)

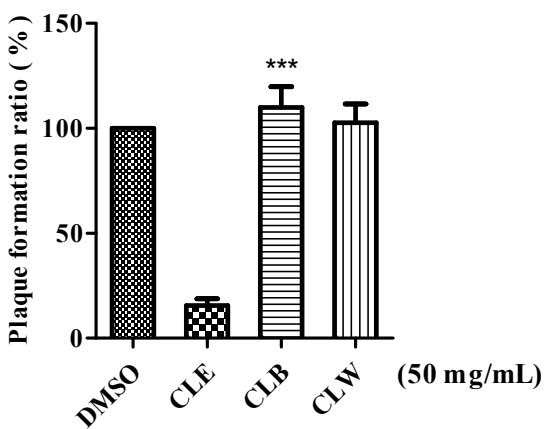

(b)

Figure 2. Anti-IAV activity of the extracts, fractions, and isolated compounds using the viral plaque reduction assay on MDCK cells with A/WSN/33 (H1N1) virus. (a) The anti-IAV activity of the CL, CF, $\mathrm{CFM}, \mathrm{CM}$, and CMA extracts. Cell viability was shown in upper panel and plaque forming reducing was shown in bottom panel. (b) The anti-IAV activity of the EtOAc (CLE), $\mathrm{BuOH}$ (CLB), and $\mathrm{H}_{2} \mathrm{O}$ (CLW) layers from CL extract. Cell viability was shown in the upper panel and plaque forming reducing is shown in the bottom panel. The data are presented as mean \pm SD of three independent experiments and were normalized to the data of solvent control $\left({ }^{*} p<0.05,{ }^{* *} p<0.01\right.$ and $\left.{ }^{* * *} p<0.001\right)$. 


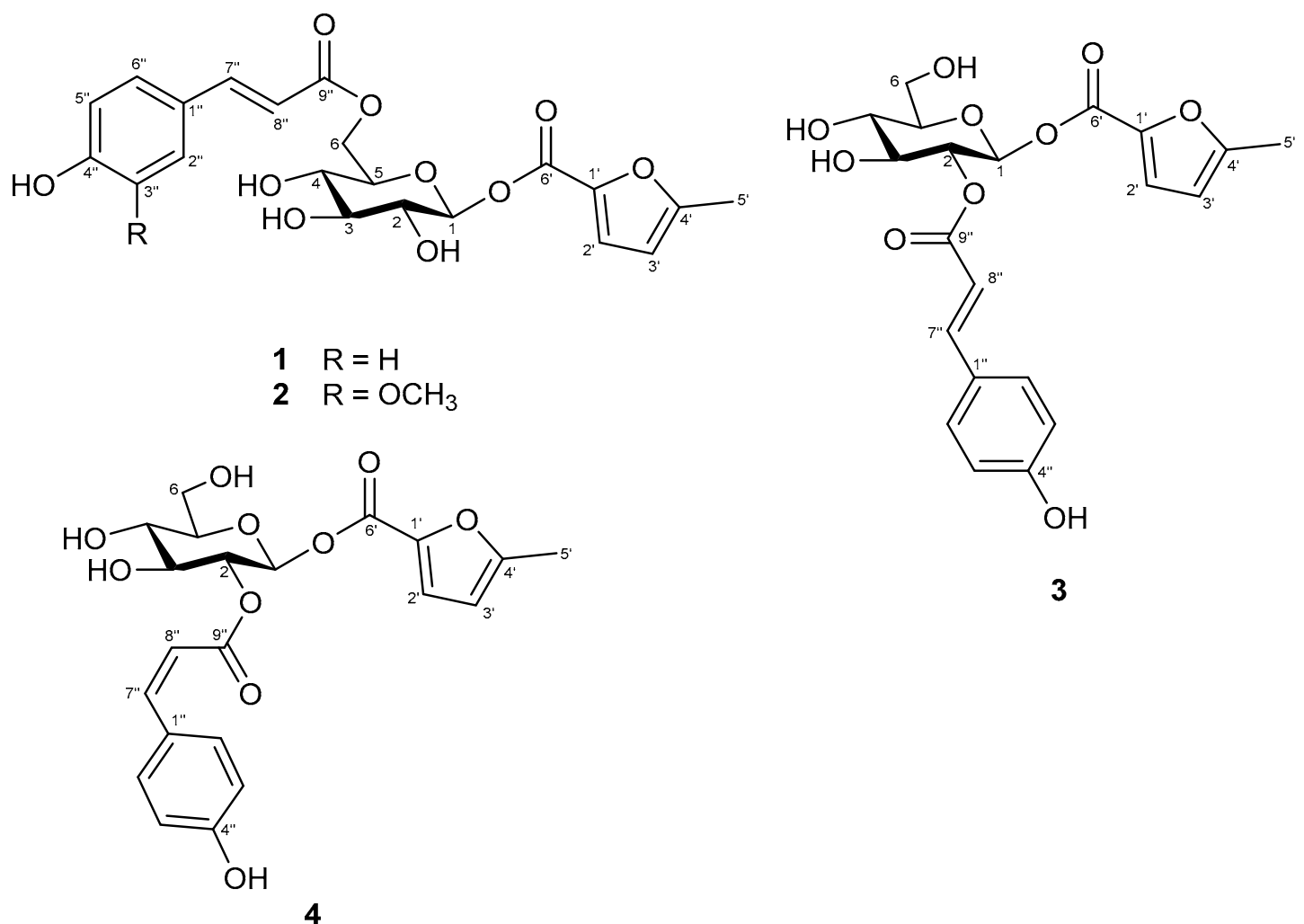

Figure 3. Chemical structures of compounds 1-4.

Table 1. ${ }^{1} \mathrm{H}-\mathrm{NMR}(500 \mathrm{MHz})$ spectroscopic data for $\mathbf{1}-\mathbf{4}$ in $\mathrm{CD}_{3} \mathrm{OD}$.

\begin{tabular}{ccccc}
\hline \multirow{2}{*}{ Position } & $\mathbf{1}$ & $\mathbf{2}$ & $\mathbf{3}$ & $\mathbf{4}$ \\
\cline { 2 - 5 } & \multicolumn{4}{c}{$\boldsymbol{\delta}_{\mathbf{H},} \mathbf{J}$ in $\mathbf{H z}$} \\
\hline 1 & $5.05(\mathrm{~d}, 7.5)$ & $5.05(\mathrm{~d}, 7.5)$ & $5.34(\mathrm{~d}, 8.0)$ & $5.25(\mathrm{~d}, 8.0)$ \\
2 & $3.46(\mathrm{dd}, 9.0,7.5)$ & $3.48(\mathrm{dd}, 8.5,7.5)$ & $5.07(\mathrm{dd}, 9.0,8.0)$ & $5.03(\mathrm{dd}, 9.0,8.0)$ \\
3 & $3.48(\mathrm{t}, 9.0)$ & $3.50(\mathrm{t}, 8.5)$ & $3.71(\mathrm{t}, 9.0)$ & $3.64(\mathrm{t}, 9.0)$ \\
4 & $3.37(\mathrm{t}, 9.0)$ & $3.39(\mathrm{t}, 8.5)$ & $3.51(\mathrm{br} \mathrm{d}, 9.0)$ & $3.47(\mathrm{t}, 9.0)$ \\
5 & $3.77(\mathrm{ddd}, 9.0,7.5,2.0)$ & $3.78(\mathrm{ddd}, 8.5,7.5,2.0)$ & $3.57(\mathrm{~m})^{\mathrm{a}}$ & $3.53(\mathrm{~m})^{\mathrm{a}}$ \\
6 & $4.23(\mathrm{dd}, 12.0,7.5)$ & $4.25(\mathrm{dd}, 12.0,7.5)$ & $3.74(\mathrm{dd}, 12.0,5.5)$ & $3.71(\mathrm{dd}, 12.0,5.0)$ \\
$2^{\prime}$ & $4.55(\mathrm{dd}, 12.0,2.0)$ & $4.57(\mathrm{dd}, 12.0,2.0)$ & $3.96(\mathrm{dd}, 12.0,2.0)$ & $3.90(\mathrm{br} \mathrm{d}, 12.0)$ \\
$3^{\prime}$ & $5.72(\mathrm{~d}, 1.0)$ & $5.74(\mathrm{~d}, 2.0)$ & $5.68(\mathrm{~d}, 2.0)$ & $5.66(\mathrm{br} \mathrm{s})$ \\
$4^{\prime}$ & $6.09(\mathrm{~d}, 1.0)$ & $6.08(\mathrm{~d}, 2.0)$ & $5.98(\mathrm{br} \mathrm{s})$ & $5.95(\mathrm{br} \mathrm{s})$ \\
$5^{\prime}$ & - & - & - & - \\
$2^{\prime \prime}$ & $2.20(\mathrm{~s})$ & $2.15(\mathrm{~s})$ & $2.16(\mathrm{~s})$ & $2.18(\mathrm{~s})$ \\
$3^{\prime \prime}$ & $7.56(\mathrm{~d}, 8.5)$ & $7.24(\mathrm{~d}, 2.0)$ & $7.43(\mathrm{~d}, 8.5)$ & $7.63(\mathrm{~d}, 8.5)$ \\
$4^{\prime \prime}$ & $6.79(\mathrm{~d}, 8.5)$ & - & $6.79(\mathrm{~d}, 8.5)$ & $6.73(\mathrm{~d}, 8.5)$ \\
$5^{\prime \prime}$ & - & - & - & \\
$6^{\prime \prime}$ & $6.79(\mathrm{~d}, 8.5)$ & $6.81(\mathrm{~d}, 8.5)$ & $6.79(\mathrm{~d}, 8.5)$ & $6.73(\mathrm{~d}, 8.5)$ \\
$7^{\prime \prime}$ & $7.56(\mathrm{~d}, 8.5)$ & $7.09(\mathrm{dd}, 8.5,2.0)$ & $7.43(\mathrm{~d}, 8.5)$ & $7.73(\mathrm{~d}, 8.5)$ \\
$8^{\prime \prime}$ & $7.60(\mathrm{~d}, 16.0)$ & $7.62(\mathrm{~d}, 16.0)$ & $7.67(\mathrm{~d}, 16.0)$ & $6.90(\mathrm{~d}, 12.5)$ \\
$\mathrm{OCH}_{3}$ & $6.37(\mathrm{~d}, 16.0)$ & $6.42(\mathrm{~d}, 16.0)$ & $6.36(\mathrm{~d}, 16.0)$ & $5.80(\mathrm{~d}, 12.5)$ \\
\hline
\end{tabular}

${ }^{\text {a }}$ Overlapped signals are reported without designating multiplicity. 
Table 2. ${ }^{13} \mathrm{C}-\mathrm{NMR}(125 \mathrm{MHz})$ spectroscopic data for $\mathbf{1}-\mathbf{4}$ in $\mathrm{CD}_{3} \mathrm{OD}$.

\begin{tabular}{|c|c|c|c|c|}
\hline \multirow{2}{*}{ Position } & 1 & 2 & 3 & 4 \\
\hline & \multicolumn{4}{|c|}{$\delta c$} \\
\hline 1 & 100.9 & 100.8 & 98.9 & 98.9 \\
\hline 2 & 74.5 & 74.4 & 74.4 & 74.4 \\
\hline 3 & 77.8 & 77.8 & 75.9 & 76.0 \\
\hline 4 & 71.7 & 71.7 & 71.1 & 71.2 \\
\hline 5 & 76.4 & 76.1 & 78.9 & 78.9 \\
\hline 6 & 64.7 & 64.7 & 62.2 & 62.2 \\
\hline $1^{\prime}$ & 167.5 & 167.3 & 167.3 & 167.3 \\
\hline $2^{\prime}$ & 92.0 & 92.1 & 91.9 & 91.9 \\
\hline $3^{\prime}$ & 101.6 & 101.6 & 101.4 & 101.4 \\
\hline $4^{\prime}$ & 164.9 & 164.8 & 165.1 & 165.1 \\
\hline $5^{\prime}$ & 19.8 & 19.9 & 19.8 & 19.8 \\
\hline $6^{\prime}$ & 171.4 & 171.3 & 171.0 & 171.5 \\
\hline $1^{\prime \prime}$ & 127.3 & 127.7 & 127.1 & 131.4 \\
\hline $2^{\prime \prime}$ & 131.5 & 111.9 & 131.4 & 133.8 \\
\hline $3^{\prime \prime}$ & 116.9 & 149.6 & 117.0 & 116.2 \\
\hline $4^{\prime \prime}$ & 161.5 & 151.0 & 161.5 & 162.3 \\
\hline $5^{\prime \prime}$ & 116.9 & 116.6 & 117.0 & 116.2 \\
\hline $6^{\prime \prime}$ & 131.5 & 124.6 & 131.4 & 133.8 \\
\hline $7^{\prime \prime}$ & 147.1 & 147.4 & 147.5 & 147.5 \\
\hline $8^{\prime \prime}$ & 114.9 & 115.1 & 114.7 & 115.9 \\
\hline $9^{\prime \prime}$ & 169.1 & 169.1 & 168.2 & 168.2 \\
\hline $\mathrm{OCH}_{3}$ & - & 56.7 & - & - \\
\hline
\end{tabular}
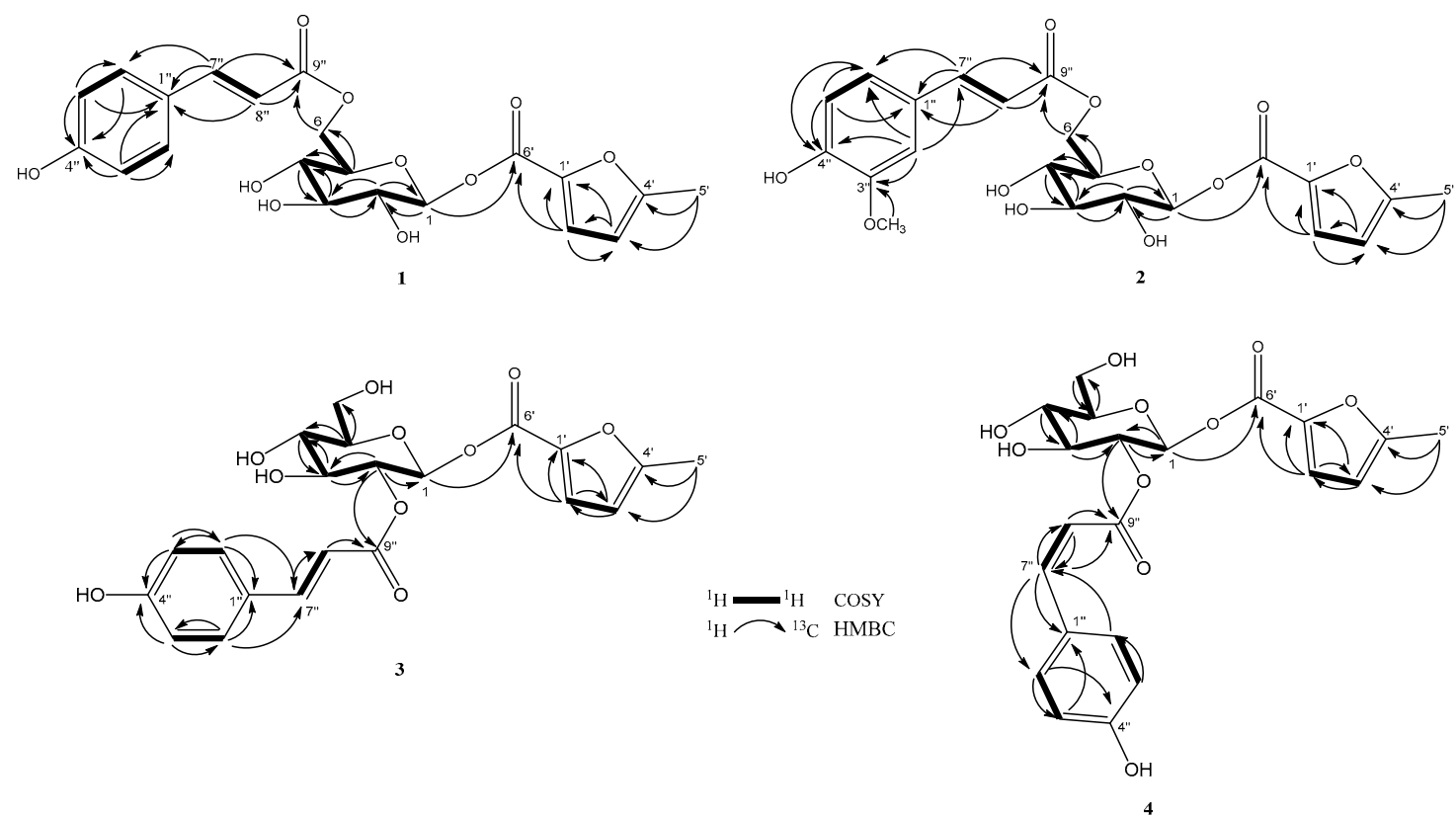

Figure 4. Key ${ }^{1} \mathrm{H}_{-}{ }^{1} \mathrm{H}$ COSY and HMBC correlations of compounds 1-4.

Compound 2 was obtained as a white amorphous powder. The molecular formula $\mathrm{C}_{22} \mathrm{H}_{24} \mathrm{O}_{11}$ was determined based on the HRESIMS ion at $m / z 503.0947[\mathrm{M}+\mathrm{K}]^{+}$(calculated for 503.0950), which showed 11 indices of unsaturation. The IR spectrum exhibited characteristic absorptions for a hydroxyl $\left(3416 \mathrm{~cm}^{-1}\right)$, a conjugated carbonyl $\left(1692 \mathrm{~cm}^{-1}\right)$, and an aromatic ring $\left(1605\right.$ and $\left.1514 \mathrm{~cm}^{-1}\right)$. Inspection of ${ }^{1} \mathrm{H}$ - and ${ }^{13} \mathrm{C}-\mathrm{NMR}$ data of compound $\mathbf{2}$ (Tables 1 and 2) indicated similar NMR features to those of $\mathbf{1}$ except that it differed in the benzoate substitution patterns and the presence of one additional methoxy group $\left(\delta_{\mathrm{H}} 3.92 / \delta_{\mathrm{C}} 56.7\right)$. In the ${ }^{1} \mathrm{H}-\mathrm{NMR}$ data revealed the $\mathrm{ABX}$ protons of a 1,3,4-trisubstituted aromatic 
ring at $\delta_{\mathrm{H}} 7.24\left(1 \mathrm{H}, \mathrm{d}, J=2.0 \mathrm{~Hz}, \mathrm{H}-2^{\prime \prime}\right), 7.09\left(1 \mathrm{H}, \mathrm{dd}, J=8.5,2.0 \mathrm{~Hz}, \mathrm{H}-6^{\prime \prime}\right)$, and $6.81(1 \mathrm{H}, \mathrm{d}, J=8.5 \mathrm{~Hz}$, $\left.\mathrm{H}-5^{\prime \prime}\right)$ which in combination with the ${ }^{13} \mathrm{C}-\mathrm{NMR}$ data suggested the appeared as a feruloyl group. The methoxy group $\left(\delta_{\mathrm{H}} 3.92\right)$ attached at $\mathrm{C}-3^{\prime \prime \prime}$ of feruloyl group were confirmed by its NOESY correlation with $\mathrm{H}-2^{\prime \prime \prime}\left(\delta_{\mathrm{H}} 7.24, \mathrm{~d}, J=2.0 \mathrm{~Hz}\right)$ and its HMBC correlation with C-3"' $\left(\delta_{\mathrm{C}} 149.6\right)$. The full chemical structure of 2 was further confirmed by ${ }^{1} \mathrm{H}^{-1} \mathrm{H}$ COSY, HSQC, and HMBC correlations (Figure 4). Thus, the structure of $\mathbf{2}$ was determined as 6-O-feruloyl-1-O-(5-methyl-2-furoyl)-1- $\beta$-D-glycopyranoside and it was named cuscutaside B.

Compound 3 was obtained as a white amorphous powder and $[\alpha]_{D}^{25}+15.3(c 0.1, \mathrm{MeOH})$. The molecular formula, $\mathrm{C}_{21} \mathrm{H}_{22} \mathrm{O}_{10}$, was deduced from HRESIMS $\left(\mathrm{m} / \mathrm{z} 457.1105[\mathrm{M}+\mathrm{Na}]^{+}\right.$, calculated 457.1105). The UV spectrum showed absorption maxima at $\lambda_{\max }$ of $205 \mathrm{and} 312 \mathrm{~nm}$. The IR absorptions at 1602,1514, and $831 \mathrm{~cm}^{-1}$ indicated an 1,4-disubstited aromatic system. The IR and UV spectra similarity of $\mathbf{3}$ with those of $\mathbf{1}$ suggested that they have a similar $p$-coumaroyl glycoside. Detailed analysis of the ${ }^{1} \mathrm{H}$ - and ${ }^{13} \mathrm{C}-\mathrm{NMR}$ spectra (Tables 1 and 2) of $\mathbf{3}$ with those of $\mathbf{1}$ indicated that most of the resonances in $\mathbf{3}$ were the same as those of $\mathbf{1}$. The significant difference between $\mathbf{1}$ and $\mathbf{3}$ was that the trans-p-coumaroyl moiety linked to C-6 of glucose in $\mathbf{1}$ and connected to C-2 of glucose in 3, which could be inferred from the $\gamma$-effect. The position of the $p$-coumaroyl moiety of $\mathbf{3}$ was compared with that of 1 , which showed upfield shifts of $C-1\left(\delta_{C} 98.9\right)$ by $2.0 \mathrm{ppm}$, of $C-3\left(\delta_{C} 75.9\right)$ by $1.9 \mathrm{ppm}$ and of C-6 $\left(\delta_{C} 62.2\right)$ due to $\gamma$-effect by $2.5 \mathrm{ppm}$ and a downfield shift of C-5 $\left(\delta_{C} 78.9\right)$ by $2.5 \mathrm{ppm}$ without $\gamma$-effect and of $\mathrm{H}-2\left(\delta_{\mathrm{H}} 5.07\right)$ by $1.61 \mathrm{ppm}$ according to $-\mathrm{OH}$ substituent change to ester function. This was further confirmed thought the observation of a HMBC correlation from $\delta_{\mathrm{H}} 5.07(\mathrm{H}-2)$ to a carbonyl carbon at $\delta_{\mathrm{C}} 168.2\left(\mathrm{C}-9^{\prime \prime}\right)$ and from $\delta_{\mathrm{H}} 6.36\left(\mathrm{H}-8^{\prime \prime}\right)$ to a carbonyl carbon at $\delta_{\mathrm{C}} 168.2\left(\mathrm{C}-9^{\prime \prime}\right)$, in addition to the consequence of ${ }^{1} \mathrm{H}_{-}{ }^{1} \mathrm{H}$ COSY correlation fragment (Figure 4) of $\delta_{\mathrm{H}} 5.34(\mathrm{H}-1) / 5.07(\mathrm{H}-2) / 3.71$ $(\mathrm{H}-3) / 3.51(\mathrm{H}-4) / 3.57(\mathrm{H}-5) / 3.74,3.96\left(\mathrm{H}_{2}-6\right)$. The chemical shift and $J$ values $(J=8.0 \mathrm{~Hz})$ of its anomeric proton indicated the $\beta$-configuration of glucose. The previously observed a further HMBC correlation of $\mathrm{H}-1$ to $\mathrm{C}-6^{\prime}$ positioned the remaining 5-methyl-2-furoyl ester at C-1. Accordingly, the structure of 3 was determined to be 2-O-(E)-p-coumaryl-1-O-(5-methyl-2-furoyl)-1- $\beta$-D-glycopyranoside and named cuscutaside C.

Compound 4 was purified as a white amorphous powder and its molecular formula of $\mathrm{C}_{21} \mathrm{H}_{22} \mathrm{O}_{10}$ was determined on the basis of HRESIMS at $m / z 433.1113\left([\mathrm{M}-\mathrm{H}]^{-}\right.$, calculated 433.1129). The spectroscopic data of 4 was very similar to and shared many features with 3 . Comparison of the NMR data (Tables 1 and 2) for 3 and 4 readily identified 4 as having the same a 5-methyl-2-furoyl unit substituted at C-1 and a p-coumaroyl moiety attached to C-2' of a glycopyranosyl moiety. However, obviously different signals were noted in the ${ }^{1} \mathrm{H}-\mathrm{NMR}$ chemical shift for $\delta_{\mathrm{H}} 6.90(\mathrm{~d}, J=12.5 \mathrm{~Hz}$, $\left.\mathrm{H}-7^{\prime \prime}\right)$ and $\delta_{\mathrm{H}} 5.80\left(\mathrm{~d}, J=12.5 \mathrm{~Hz}, \mathrm{H}-8^{\prime \prime}\right)$ of 4 compared to 3 . The geometry of double bonds was determined to be cis by the magnitude of the coupling constant $J_{\mathrm{H}-7^{\prime \prime} / 8^{\prime \prime}}(12.5 \mathrm{~Hz})$. In the HMBC spectrum, $\delta_{\mathrm{H}} 5.03(\mathrm{H}-2), 6.90\left(\mathrm{H}-7^{\prime \prime}\right)$, and $5.80\left(\mathrm{H}-8^{\prime \prime}\right)$ exhibited interactions with $\delta_{\mathrm{C}} 168.2\left(\mathrm{C}-9^{\prime \prime}\right)$. The relative configuration of glucosyl moiety was also determined through both NOESY correlations and coupling constants. The magnitude of the coupling constants for $\mathrm{H}-1(\mathrm{~J}=8.0 \mathrm{~Hz})$ was also constructive of axial-axial couplings and established a $\beta$-D-glucose moiety. Thus, compound 4 was deduced as 2-O-(Z)-p-coumaryl-1-O-(5-methyl-2-furoyl)-1- $\beta$-D-glycopyranoside and named cuscutaside D.

Twenty-six known metabolites were isolated and identified as four aromatic glycosides, 6-O-pcoumaroyl-glucopyranose (5), 6'-O-cinnamoyl-glucopyranose (6) [13], 6'-O-(E)-p-coumaroyl-2-O- $\beta$ D-glucopyranosyl- $\alpha$-D-glucopyranoside (7) [14], and 4-(E)-p-coumaroyl-glucopyranose (8) [15], two caffeoylquinic acid derivatives, 3,5-dicaffeoylquinic acid (9) [16], and methyl 3,5-dicaffeoylquinate (10), five lignans, clemaphenol A (11) [17], (+)-pinoresinol (12), (+)-syringaresinol (13) [18], bombasinol A (14) [19], and (+)-epipinoresinol (15) [20], four tropane alkaloids, $p$-coumaroyltyramine (16) [21], N-trans-feruloytyramine (17) [22], N-(p-cis-coumaroyl)tyramine (18) [23], and N-cisferuloyltyramine (19) [24], two indole alkaloids, indole-3-carboxaldehyde (20) [25], and indole-3carboxylic acid (21) [26], five flavonoids, querectin (22) [27], querectin-3-O-glucopyranoside (23) [28], quercetin-3-O- $\beta$-D-glucopyranosyl-( $1 \rightarrow 4)-\beta$-D-glucopyranoside (24), $4^{\prime}$-O-methylquercetin-3-O- $\beta$-D- 
glucopyranoside (25) [29], and 3,5,7,3'-tetrahydroxy-4'-methoxyisoflavanone (26) [30], two aromatic compounds, trans-4-hydroxycinnamic acid (27) [31], and methyl 3,4-dihydroxycinnamate (28) [32], two fatty acids, 1-monopalmitin (29) and 1- $\alpha$-linolenoylglycerol (30) [33] by comparing their physical and spectroscopic data with those reported in the literature. These compounds were obtained from this plant for the first time. The phytochemical composition of the 16 marker compounds from the whole plant Japanese dodder parasitizing on D. longans Lour. (CL) was investigated by HPLC (Figure 5).

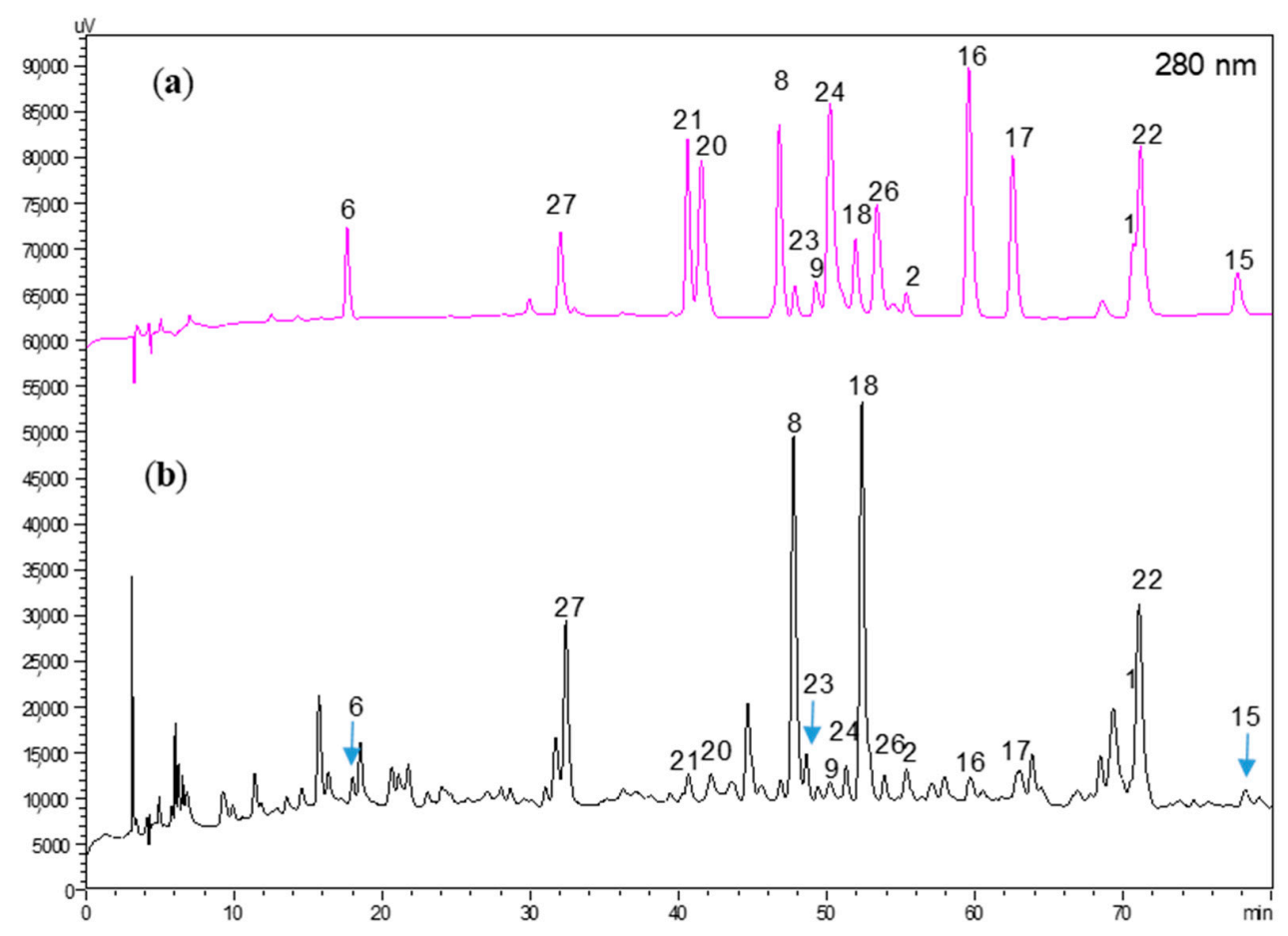

Figure 5. HPLC chromatograms of (a) the 16 marker compounds and (b) the CLE layer at optimum detection wavelength $(280 \mathrm{~nm})$.

\subsection{Antiviral Activity against Influenza A Virus (IVA)}

Some of the isolated compounds $(\mathbf{1}-4,9,10,13,15-17,19,21,22$, and 26-30) were further evaluated for their antiviral activity against IAV (A/WSN/1933(H1N1)) (Figure 6). The results indicated that fatty acids 29 and $\mathbf{3 0}$ possessed high antiviral activities against IAV. The most effective compound $\mathbf{2 9}$ were further evaluated the different stages of viral infection by plaque reduction assay (Figure 7a). Compound 29 was found to effectively inhibit the entry step of IAV into cells (Figure 7b). The values of $\mathrm{EC}_{50}$ is $2.28 \pm 0.04 \mu \mathrm{M}$ and $\mathrm{EC}_{90}$ value is $4.77 \pm 0.17 \mu \mathrm{M}$ (Figure $7 \mathrm{c}$ ).

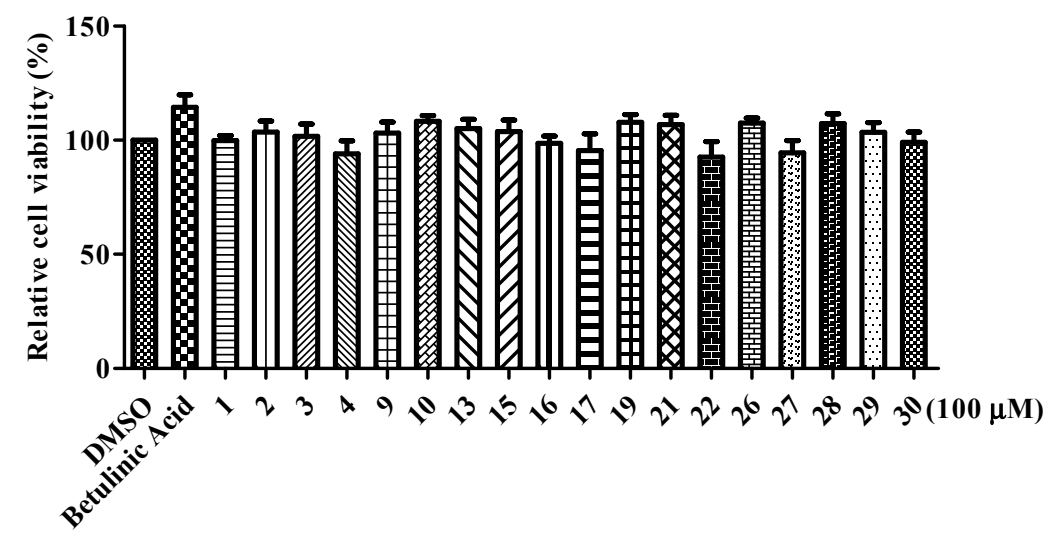

Figure 6. Cont. 


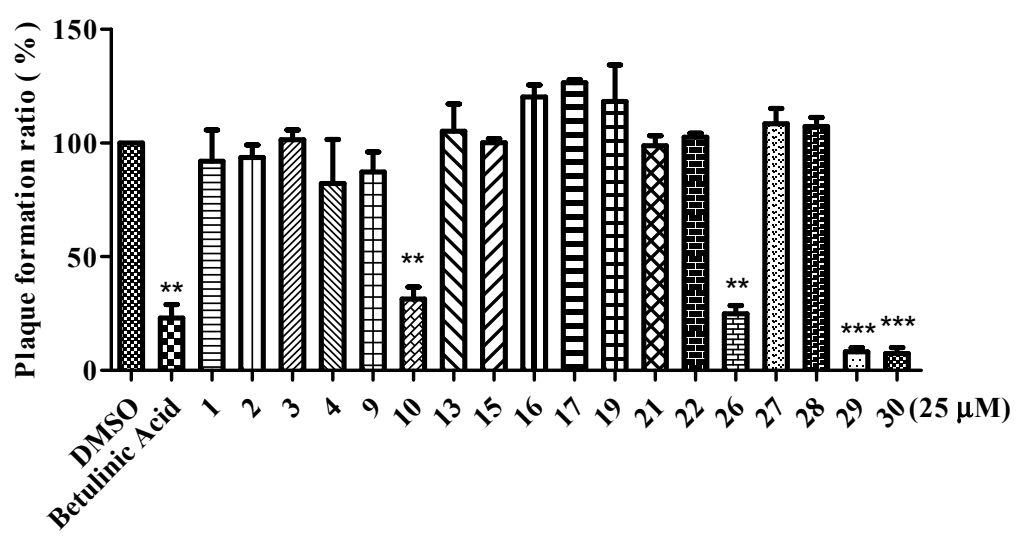

Figure 6. Anti-IAV activity of isolated compounds from the CLE layer. Cell viability is shown in the upper panel and plaque forming reducing shown in the bottom panel. DMSO was used as a solvent control and betulinic acid was used as a positive control. The data are presented as mean \pm SD of three independent experiments and were normalized to the data of solvent control $(* * p<0.01$, and *** $p<0.001)$.

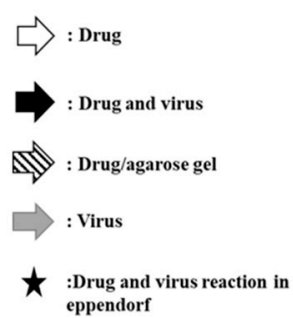
eppendorf

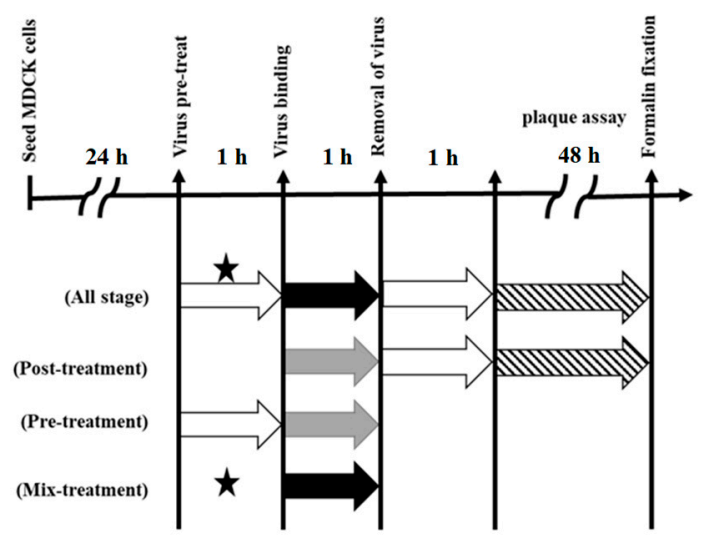

(a)

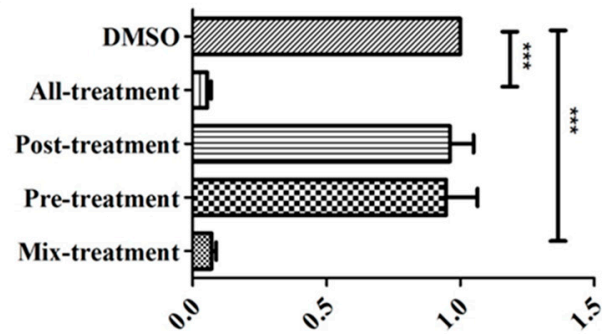

(b)

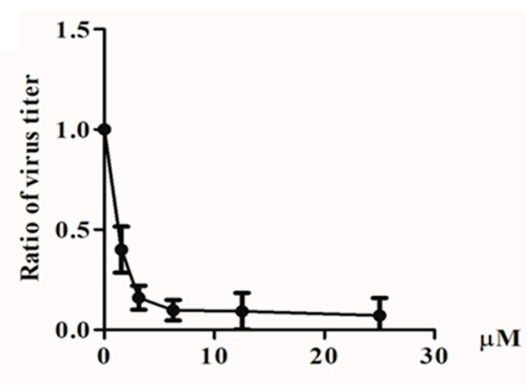

(c)

Figure 7. Anti-IAV assay of 1-monopalmitin (29). (a) Schematic representation of the strategies used to test the anti-IAV activity. (b) MDCK cells were infected with IAV (A/WSN/1933(H1N1)) and treated with 29 at the concentration of $\mathrm{EC}_{90}$ at the indicated time according to the different strategy presented above. (c) Anti-IAV activities of different concentration of 29. DMSO was used as a solvent control. The data are presented as mean \pm SD of three independent experiments and were normalized to the solvent control data $\left.{ }^{* * *} p<0.001\right)$.

\section{Discussion}

Comparative profiling of metabolites by HPLC-DAD in five Japanese dodders after attachment to different hosts revealed several metabolic changes and amounts. Japanese dodders parasitizing on different plants exhibited distinct anti-virus activation depending on the host. The investigation of 
Japanese dodder parasitizing on D. longans Lour. (CL) and its EtOAc fractions (CLE) showed it can effectively inhibits IAV. In this work, four new compounds 1-4 and twenty-six known compounds 5-30 were isolated from Japanese dodder (CL). It is interesting to note that 1-monopalmitin (29), a simple glycerol esterified fatty acid which has a role as a plant metabolite, was found to be one of anti-IAV (A/WSN/1933(H1N1)) substances from the whole plant Japanese dodder (CL). Moreover, the two fatty acids 1-monopalmitin (29) and 1- $\alpha$-linolenoylglycerol (30) were more potent than betulinic acid which was used as a positive control. The fully saturated (C19:0) fatty acid, 1-monopalmitin (29) showed higher antiviral activities against IAV than the unsaturated (C21:3) fatty acid 30. The current results suggest that fully saturated fatty acids play a crucial role in the anti-influenza virus activity that was observed.

\section{Materials and Methods}

\subsection{General}

1D- and 2D-NMR spectra were recorded using a Bruker DRX-500 spectrometer (Bruker Instruments, Karlsruhe, Germany) with $\mathrm{CD}_{3} \mathrm{OD}$ as the solvent. Infrared (IR) spectra, optical rotations, and UV spectra were measured using a JASCO FT/IR-480 plus spectrometer, a JASCO P-1020 polarimeter and a JASCO V-550 UV/Vis spectrometer, respectively (JASCO International Co. Ltd., Tokyo, Japan). HRESIMS data were obtained using a maXis impact Q-TOF mass spectrometer (Bruker Daltonik, Bremen, Germany). Sephadex LH-20 (GE healthcare, Chicago, IL, USA), Diaion HP-20 (Mitsubishi Chemical Corporation, Kyoto, Japan) and silica gel (Merck 70-230 mesh and 230-400 mesh) (Merck \& Co. Inc. Darmstadt, Germany) were used for the column chromatography. The analysis HPLC was performed on a Shimadzu LC-20AT series apparatus (Shimadzu Co., Kyoto, Japan) with a prominence SPD-M20A diode array detector, a SIL-20A prominence Auto sampler, and a CTO-20A prominence column oven, using a reverse phase column (Cosmosil 5C18-AR-II column, $5 \mu \mathrm{m}$ particle size, $250 \mathrm{~mm} \times 4.6 \mathrm{~mm}$ i.d.) (Merck \& Co., Inc., NJ, USA). Preparative HPLC was performed using a reverse phase column (Cosmosil 5C18-AR-II column, $5 \mu \mathrm{m}$ particle size, $250 \mathrm{~mm} \times 10 \mathrm{~mm}$ i.d.) (Merck \& Co., Inc., NJ, USA) using a Shimadzu LC-6AD series apparatus with a RID-10A Refractive Index detector (Shimadzu Co.). MPLC was performed using a reverse phase column (Buchi MPLC glass column, C18, $460 \mathrm{~mm} \times 36 \mathrm{~mm}$ i.d.) on a Buchi pump module C-601 series apparatus (Buchi Ltd., Flawi, Switzerland) without a detector. The 1D and 2D NMR spectral data of compounds 1-4 can be found at Supplementary Materials.

\subsection{Plant Material}

Whole C. japonica on D. longans Lour. plants used in this experiment were collected on the mountains of Nantou County, Taiwan, in August 2012. The parasitic plant was identified by Dr. Shy-Yuan Hwang, Endemic Species Research Institute. A voucher specimen of $C$. japonica on D. longans Lour. (No. CMR201208CL) was deposited in the Department of Chinese Pharmaceutical Sciences and Chinese Medicine Resources, China Medical University, Taichung, Taiwan.

\subsection{Extraction and Isolation}

Whole C. japonica $(10 \mathrm{~kg})$ plants were sectioned and extracted three times with $\mathrm{MeOH}(20 \mathrm{~L})$ for $72 \mathrm{~h}$ each time. The $\mathrm{MeOH}$ extract was continuously dried under reduced pressure at $45^{\circ} \mathrm{C}$ to yield a brown syrup (ca. $988 \mathrm{~g}$ ). The combined extracts were suspended on $\mathrm{H}_{2} \mathrm{O}(2 \mathrm{~L}$ ) and then partitioned with EtOAc (2 L) and $n$-BuOH (2 L), successively. The EtOAc layer (ca. $600 \mathrm{~g}$ ) was subjected to a silica gel CC $(15 \times 50 \mathrm{~cm}$ i.d., Merck 70-230 mesh), eluting with $n$-hexane/EtOAc (40:1, 20:1, 10:1, 5:1, 1:1, 0:1, v/v) and $\mathrm{EtOAc} / \mathrm{MeOH}(10: 1,5: 1,4: 1, v / v)$ in a gradient to give ten fractions (fr. 1 11). Fraction 5 (20.1 g) was subjected to Sephadex LH-20 column $(3 \times 90 \mathrm{~cm}$, i.d.) chromatography eluting with $\mathrm{CH}_{2} \mathrm{Cl}_{2} / \mathrm{MeOH}$ to yield 9 subfractions (fr. 5.1-5.9). Fr. $5.3(453.5 \mathrm{mg})$ was subjected to reverse phase (RP) MPLC $\left(\mathrm{C}_{18}\right.$ gel, $3 \times 60 \mathrm{~cm}$ i.d., flow rate: $\left.20 \mathrm{~min} / \mathrm{mL}\right)$ with gradient $\mathrm{MeOH} / \mathrm{H}_{2} \mathrm{O}(40 / 60$ to 
100/0, $v / v$ ) to yield 8 subfractions (fr. 5.3.1 5.3.8). Fr. 5.3.1 (165.5 mg) was chromatographed using preparative RP-HPLC (Cosmosil 5C 18 -AR-II column, flow rate: $3.0 \mathrm{~min} / \mathrm{mL}$ ) with $38 \% \mathrm{MeOH}$ in $\mathrm{H}_{2} \mathrm{O}$ to yield $13\left(8.5 \mathrm{mg}, \mathrm{t}_{\mathrm{R}}=46.3 \mathrm{~min}\right), \mathbf{1 4}\left(2.3 \mathrm{mg}, \mathrm{t}_{\mathrm{R}}=53.1 \mathrm{~min}\right)$, and $\mathbf{1 8}\left(4.4 \mathrm{mg}, \mathrm{t}_{\mathrm{R}}=23.8 \mathrm{~min}\right)$. Using preparative RP-HPLC (Cosmosil 5C 18 -AR-II column, flow rate: $3.0 \mathrm{~min} / \mathrm{mL}$ ) with $43 \% \mathrm{MeOH}, 15$ $\left(8.8 \mathrm{mg}, \mathrm{t}_{\mathrm{R}}=44.8 \mathrm{~min}\right)$ were obtained from fr. $5.3 .3(32.4 \mathrm{mg})$. The subfraction 5.3 .6 was subjected to RP-HPLC with $45 \% \mathrm{MeOH}$ to obtain $29\left(42.9 \mathrm{mg}, \mathrm{t}_{\mathrm{R}}=24.1 \mathrm{~min}\right)$, and $30\left(59.1 \mathrm{mg}, \mathrm{t}_{\mathrm{R}}=25.6 \mathrm{~min}\right)$. Fraction $5.4(1.98 \mathrm{~g})$ was subjected to RP-MPLC $\left(\mathrm{C}_{18} \mathrm{gel}, 3 \times 60 \mathrm{~cm}\right.$, flow rate: $\left.20 \mathrm{~min} / \mathrm{mL}\right)$ with gradient $\mathrm{MeOH} / \mathrm{H}_{2} \mathrm{O}$ (30:70 to 100:0, $v / v$ ) to yield 10 subfractions (fr. 5.4.1 5.4.10). Fr. 5.4.2 (293.1 mg) was subjected to preparative RP-HPLC (flow rate: $3.0 \mathrm{~min} / \mathrm{mL}$ ), eluting with $60 \% \mathrm{MeOH}$ to yield 7 fractions (fr. 5.4.2.1 5.4.2.7). Fr. 5.4.2.4 (40.9 mg) was chromatographed using RP-HPLC with $43 \% \mathrm{MeOH}$ to yield $27\left(16.2 \mathrm{mg}, \mathrm{t}_{\mathrm{R}}=13.8 \mathrm{~min}\right) .12\left(5.2 \mathrm{mg}, \mathrm{t}_{\mathrm{R}}=32.5 \mathrm{~min}\right)$ was isolated from fr. 5.4.2.6 $(40.5 \mathrm{mg})$ by RP-HPLC (flow rate: $3.0 \mathrm{~min} / \mathrm{mL}$ ), eluting with $43 \% \mathrm{MeOH}$. Fr. $5.4 .3(41.7 \mathrm{mg}$ ) was subjected to Sephadex LH-20 column $(3 \times 90 \mathrm{~cm}$, i.d.) chromatography eluting with $\mathrm{MeOH}$ to yield 6 subfractions (fr. 5.4.3.1 5.4.3.6). Fr. 5.4.3.4 (141.7 mg) was purified by RP-HPLC ( $45 \% \mathrm{MeOH})$ to yield compounds $26\left(24.4 \mathrm{mg}, \mathrm{t}_{\mathrm{R}}=17.8 \mathrm{~min}\right) . \mathbf{1 6}\left(30.0 \mathrm{mg}, \mathrm{t}_{\mathrm{R}}=27.8 \mathrm{~min}\right)$ was separated by RP-HPLC with $45 \% \mathrm{MeOH}$ from fr. $5.4 .5(149.3 \mathrm{mg})$. Fr. $5.4 .6(293.8 \mathrm{mg})$ was subjected to preparative RP-HPLC, eluting with $43 \% \mathrm{MeOH}$ to yield $21\left(4.8 \mathrm{mg}, \mathrm{t}_{\mathrm{R}}=12.0 \mathrm{~min}\right), \mathbf{2 0}\left(4.9 \mathrm{mg}, \mathrm{t}_{\mathrm{R}}=17.0 \mathrm{~min}\right), \mathbf{1 9}\left(7.3 \mathrm{mg}, \mathrm{t}_{\mathrm{R}}=17.8 \mathrm{~min}\right), \mathbf{2 8}$ $\left(61.9 \mathrm{mg}, \mathrm{t}_{\mathrm{R}}=22.1 \mathrm{~min}\right), \mathbf{1 7}\left(55.7 \mathrm{mg}, \mathrm{t}_{\mathrm{R}}=28.3 \mathrm{~min}\right)$, and $\mathbf{1 1}\left(75.5 \mathrm{mg}, \mathrm{t}_{\mathrm{R}}=31.5 \mathrm{~min}\right)$. Using Sephadex LH-20 column $(1.5 \times 100 \mathrm{~cm}$, i.d.) with isocratic $\mathrm{MeOH}, 22(102.1 \mathrm{mg})$ and $23(6.9 \mathrm{mg})$ were obtained from fr. $5.8(1.67 \mathrm{~g})$. Fr. $8(14.72 \mathrm{~g})$ was subjected to Sephadex LH-20 column $(1.5 \times 100 \mathrm{~cm}$, i.d.) chromatography eluting with $\mathrm{MeOH}$ to yield 12 subfractions (fr. 8.1 8.12). Fraction 8.7 (2.76 g) was subjected to RP-MPLC $\left(\mathrm{C}_{18}\right.$ gel, $3 \times 60 \mathrm{~cm}$, flow rate: $\left.20 \mathrm{~min} / \mathrm{mL}\right)$ with gradient $\mathrm{MeOH} / \mathrm{H}_{2} \mathrm{O}(40: 60$ to $100: 0, v / v$ ) to yield 8 subfractions (fr. 8.7.1 8.7.8). Using preparative RP-HPLC with $50 \% \mathrm{MeOH}, 1$ $\left(78.3 \mathrm{mg}, \mathrm{t}_{\mathrm{R}}=44.8 \mathrm{~min}\right), 2\left(6.3 \mathrm{mg}, \mathrm{t}_{\mathrm{R}}=2.3 \mathrm{~min}\right), 3\left(26.1 \mathrm{mg}, \mathrm{t}_{\mathrm{R}}=40.8 \mathrm{~min}\right)$, and $4\left(4.9 \mathrm{mg}, \mathrm{t}_{\mathrm{R}}=39.1 \mathrm{~min}\right)$ were obtained from fr. 8.7.1 (650.5 mg). Subfraction 8.7.2 was further purified by RP-HPLC with $45 \%$ $\mathrm{MeOH}$ to give $5\left(2.5 \mathrm{mg}, \mathrm{t}_{\mathrm{R}}=17.8 \mathrm{~min}\right), \mathbf{6}\left(2.0 \mathrm{mg}, \mathrm{t}_{\mathrm{R}}=21.5 \mathrm{~min}\right)$, and $\mathbf{7}\left(3.4 \mathrm{mg}, \mathrm{t}_{\mathrm{R}}=18.2 \mathrm{~min}\right)$. Fr. 8.11 $(60.8 \mathrm{mg})$ was further separated by RP-HPLC with $50 \% \mathrm{MeOH}$ to yield $8\left(181.8 \mathrm{mg}, \mathrm{t}_{\mathrm{R}}=7.5 \mathrm{~min}\right)$, $9\left(7.7 \mathrm{mg}, \mathrm{t}_{\mathrm{R}}=10.9 \mathrm{~min}\right), \mathbf{1 0}\left(17.8 \mathrm{mg}, \mathrm{t}_{\mathrm{R}}=16.5 \mathrm{~min}\right), \mathbf{2 4}\left(4.1 \mathrm{mg}, \mathrm{t}_{\mathrm{R}}=14.3 \mathrm{~min}\right)$ and $25(9.1 \mathrm{mg}$, $\left.\mathrm{t}_{\mathrm{R}}=9.6 \mathrm{~min}\right)$.

\subsection{Spectroscopic Data}

Cuscutaside $A$ (1). White amorphous powder. $[\alpha]_{\mathrm{D}}^{25}-86.0(c 0.1, \mathrm{MeOH}) ; \mathrm{UV}(\mathrm{MeOH}) \lambda_{\max }(\log \varepsilon) 207$ (4.0), 227 (3.8), 309 (4.1) nm; IR (KBr) $\nu_{\max }$ 3361, 1693, 1604, 1564, 1514, 1448, 1246, 1170, 1074, 1018, $831,520 \mathrm{~cm}^{-1} ;{ }^{1} \mathrm{H}$ - and ${ }^{13} \mathrm{C}-\mathrm{NMR}$ data $\left(\mathrm{CD}_{3} \mathrm{OD}\right)$ see Tables 1 and 2; HRESIMS $\mathrm{m} / z$ 433.1123 [M - H] ${ }^{-}$ (calculated for $\mathrm{C}_{21} \mathrm{H}_{21} \mathrm{O}_{10}, 433.1129$ ).

Cuscutaside B (2). White amorphous powder. $[\alpha]_{\mathrm{D}}^{25}-21.0$ (c 0.1, MeOH); UV (MeOH) $\lambda_{\max }(\log \varepsilon) 207$ (4.0), 308 (4.1) nm; IR (KBr) $v_{\max } 3416,1692,1632,1605,1565,1514,1451,1246,1180,1075,822 \mathrm{~cm}^{-1}$; ${ }^{1} \mathrm{H}$ - and ${ }^{13} \mathrm{C}-\mathrm{NMR}$ data $\left(\mathrm{CD}_{3} \mathrm{OD}\right)$ see Tables 1 and 2; HRESIMS $\mathrm{m} / \mathrm{z} 503.0947[\mathrm{M}+\mathrm{K}]^{+}$(calculated for $\left.\mathrm{C}_{22} \mathrm{H}_{24} \mathrm{O}_{11} \mathrm{~K}, 503.0950\right)$.

Cuscutaside $C$ (3). White amorphous powder. $[\alpha]_{\mathrm{D}}^{25}+15.3(c 0.1, \mathrm{MeOH}) ; \mathrm{UV}(\mathrm{MeOH}) \lambda_{\max }(\log \varepsilon) 205$ (4.0), 228 (3.7), 312 (4.0) nm; IR (KBr) $\nu_{\max }$ 3352, 1695, 1631, 1602, 1566, 1514, 1450, 1246, 1166, 1083, $1024,831,516 \mathrm{~cm}^{-1} ;{ }^{1} \mathrm{H}$ - and ${ }^{13} \mathrm{C}-\mathrm{NMR}$ data $\left(\mathrm{CD}_{3} \mathrm{OD}\right)$ see Tables 1 and 2; HRESIMS $m / z$ 457.1105 [M + $\mathrm{Na}]^{+}$(calculated for $\mathrm{C}_{21} \mathrm{H}_{22} \mathrm{NaO}_{10}, 457.1105$ ).

Cuscutaside D (4). White amorphous powder. $[\alpha]_{\mathrm{D}}^{25}-19.6(c 0.1, \mathrm{MeOH}) ; \mathrm{UV}(\mathrm{MeOH}) \lambda_{\max }(\log \varepsilon) 203$ (3.9), 299 (3.2), 311 (3.2) nm; IR (KBr) $v_{\max }$ 3375, 1695, 1633, 1602, 1566, 1514, 1450, 1246, 1166, 1083, $1024,831,526 \mathrm{~cm}^{-1} ;{ }^{1} \mathrm{H}$ - and ${ }^{13} \mathrm{C}-\mathrm{NMR}$ data $\left(\mathrm{CD}_{3} \mathrm{OD}\right)$ see Tables 1 and 2; HRESIMS $\mathrm{m} / z 433.1113$ [M $\mathrm{H}]^{-}$(calculated for $\mathrm{C}_{21} \mathrm{H}_{21} \mathrm{O}_{10}, 433.1129$ ). 


\subsection{HPLC-DAD Analysis}

Five methanol crude extracts, EtOAc layer (CLE) and isolated compounds were diluted in $\mathrm{MeOH}$ (conc. $1.0 \mathrm{mg} / \mathrm{mL}$ ), respectively. All samples were filtered through a filter cartridge (pore size of $0.22 \mu \mathrm{m}$ ) prior to analyses. The HPLC profiles of crude extracts, CLE fraction and the isolated compounds were performed on a RP- 18 column at a flow rate of $1.0 \mathrm{~mL} / \mathrm{min}$ and detected at 254 and $280 \mathrm{~nm}$. The injection volume was $5 \mu \mathrm{L}$. The separation was performed using a mixture of $0.1 \%$ trifluoroacetic acid (TFA) water solution (A) and methanol (B) with the gradient elution: $0-120 \mathrm{~min}$ from $5 \% \mathrm{~B}$ to $55 \% \mathrm{~B}$.

\subsection{Anti-Inflluenza Virus Assay}

The anti-IAV activity was displayed using plaque reduction assay as described previously [34]. In brief, the five crude extracts (CL, CF, CFM, CM and CMA), three fractions (CLE, CLW, and CLW), compounds $(1-4,9,10,13,15-17,19,22-24$, and 26-30) cytotoxicity were determined by MTS cell viability assay at the concentration of $100 \mu \mathrm{M}$ of each samples in MDCK cells in the first. MDCK cells were cultured in DMEM, supplemented with $10 \%$ fetal bovine serum (Gibco, Carlsbad, CA, USA) and $1 \%$ penicillin and streptomycin (PS; HyClone, Marlborough, MA, USA) at $37^{\circ} \mathrm{C}$ with $5 \% \mathrm{CO}_{2}$ incubation. The non-cytotoxic samples were selected to the following plaque reduction assay. MDCK cells $\left(2 \times 10^{6}\right.$ cells/well) were pre-seeded in a six-well plate at $37^{\circ} \mathrm{C}$ overnight. The cell monolayer cells was then infected with influenza virus (A/WSN/1933 (H1N1), 100 PFU/well) with $25 \mu \mathrm{M}$ of each samples and the plaque forming assay was performed. The anti-IAV activity of each sample was calculated using the plaque number compared with that of the virus infected control. The most effective compound 29, was used to further perform the dose dependent plaque reduction assay. The $50 \%$ and $90 \%$ effective concentrations $\left(\mathrm{EC}_{50}\right.$ and $\mathrm{EC}_{90}$ ) were defined as the concentration required for $50 \%$ and $90 \%$ inhibition of virus infection, respectively.

\subsection{Time-Of-Addition Assay}

To determine the stage of at which 1-monopalmitin (29) inhibits IAV infection, three time points, including post-treatment, pre-treatment and mix-treatment, were used as previous study [34]. In brief, for the stage of post treatment, the viruses infected the cells for $1 \mathrm{~h}$ and the cells were overlaid with $0.3 \%$ agarose gel containing the compound for $48 \mathrm{~h}$. The effect of 1-monopalmitin inhibits IAV at post-infection stage was determined using the virus plaque reduction assay. For the stage of Pre-treatment, the cells were pretreated with 1-monopalmitin for $1 \mathrm{~h}$ followed by virus infection of the pre-treated cells for another $1 \mathrm{~h}$. After the virus removed, plaque reduction assay were performed. For the stage of Mix-treatment, the viruses were pretreated with 1-monopalmitin for $1 \mathrm{~h}$, and then the mixture of compound and viruses was added to the cells for another $1 \mathrm{~h}$. After the mixture remove, plaque reduction assay were performed.

\section{Conclusions}

Bioactivity-guided isolation of Japanese dodder (CL) let to the isolation and identification of four new compounds 1-4 and twenty-six known compounds 5-30. The structures were established via extensive spectroscopic investigations, including $1 D$ and 2D NMR, UV, IR and HRESIMS techniques. The eighteen isolated compounds were evaluated for antiviral activity against IAV activity. 1-Monopalmitin (29) exhibits potential to be developed as a promising agent against influenza virus infection. This study is important as it explain the chemical and biological diversity of the whole plant Japanese dodder parasitizing on D. longans Lour. Furthermore, the results provide invaluable information for the new application of the harmful weed.

Supplementary Materials: The 1D and 2D NMR spectra of compounds 1-4 are available online.

Author Contributions: Conceptualization, H.-C.H.; methodology, H.-C.H. and J.-C.C.; formal analysis, C.-C.L., M.-K.L., C.-J.C., C.-L.C., C.-H.C., Y.-P.C. and Y.-S.P.; data curation, C.-C.L.; writing-original draft preparation, 
H.-C.H. and J.-C.C.; supervision, Y.-H.K. All authors have read and agreed to the published version of the manuscript.

Funding: This research was funded by Ministry of Science and Technology, grant number MOST 103-2320-B-039-009 and NSC 102-2320-B-039-015 and China Medical University, grant number CMU108-S-35.

Acknowledgments: The authors would like to acknowledge the Proteomics Research Core Laboratory, Office of Research \& Development at China Medical University for mass spectrometric analyses.

Conflicts of Interest: The authors declare no conflict of interest.

\section{References}

1. Li, R.; Liu, T.; Liu, M.; Chen, F.; Liu, S.; Yang, J. Anti-influenza A virus activity of dendrobine and its mechanism of action. J. Agric. Food Chem. 2017, 65, 3665-3674. [CrossRef]

2. Chen, X.; Liu, S.; Goraya, M.U.; Maarouf, M.; Huang, S.; Chen, Y. Host immune response to influenza A virus infection. Front. Immunol. 2018, 9, 320. [CrossRef] [PubMed]

3. Hussain, M.; Galvin, H.D.; Haw, T.Y.; Nutsford, A.N.; Husain, M. Drug Resistance in Influenza A Virus: The Epidemiology and Management. Infect. Drug Resist. 2017, 10, 121-134. [CrossRef]

4. Lee, J.Y.; Abundo, M.E.C.; Lee, C.W. Herbal medicines with antiviral activity against the influenza virus, a systematic review. Am. J. Chin. Med. 2018, 46, 1663-1700. [CrossRef] [PubMed]

5. George, W.; Yang, S.Z. Convolvulaceae. In Flora of Taiwan, 2nd ed.; Editorial Committee of the Flora of Taiwan, Ed.; Department of Botany, National Taiwan University: Taipei, Taiwan, 1998; Volume 4, pp. 344-347.

6. Lin, M.K.; Lee, M.S.; Chang, W.T.; You, B.J. Extract and Method for Preparing the Same and Uses of Cuscuta sp. TWI382845B, 21 January 2013.

7. Donnapee, S.; Li, J.; Yang, X.; Ge, A.H.; Donkor, P.O.; Gao, X.; Chang, Y. Cuscuta chinensis Lam.: A systematic review on ethnopharmacology, phytochemistry and pharmacology of an important traditional herbal medicine. J. Ethnopharmacol. 2014, 157, 292-308. [CrossRef] [PubMed]

8. Liao, J.C.; Chang, W.T.; Lee, M.S.; Chiu, Y.J.; Chao, W.K.; Lin, Y.C.; Lin, M.K.; Peng, W.H. Antinociceptive and anti-inflammatory activities of Cuscuta chinensis seeds in mice. Am. J. Chin. Med. 2014, 42, $223-242$. [CrossRef]

9. Ye, M.; Yan, Y.; Guo, D.A. Characterization of phenolic compounds in the Chinese herbal drug Tu-Si-Zi by liquid chromatography coupled to electrospray ionization mass spectrometry. Rapid Commun. Mass Spectrom. 2005, 19, 1469-1484. [CrossRef]

10. Du, X.M.; Kohinata, K.; Kawasaki, T.; Guo, Y.T.; Miyahara, K. Components of the ether-insoluble resin glycoside like fraction from Cuscuta chinensis. Phytochem. 1998, 48, 843-850. [CrossRef]

11. Amarasinghe, N.R.; Jayasinghe, U.; Hara, N.; Fujimoto, Y. Flacourside, a new 4-oxo-2-cyclopentenylmethyl glucoside from the fruit juice of Flacourtia indica. Food Chem. 2007, 102, 95-97. [CrossRef]

12. Huang, H.C.; Chao, C.L.; Liaw, C.C.; Hwang, S.Y.; Kuo, Y.H.; Chang, T.C.; Chao, C.H.; Chen, C.J.; Kuo, Y.H. Hypoglycemic constituents isolated from Trapa natans L. pericarps. J. Agric. Food Chem. 2016, 64, 3794-3803. [CrossRef] [PubMed]

13. Choudhary, M.I.; Naheed, N.; Abbaskhan, A.; Ali, S. Hemiterpene glucosides and other constituents from Spiraea canescens. Phytochemistry 2009, 70, 1467-1473. [CrossRef] [PubMed]

14. Matsufuji, H.; Otsuki, T.; Takeda, T.; Chino, M.; Takeda, M. Identification of reaction products of acylated anthocyanins from red radish with peroxyl radicals. J. Agric. Food Chem. 2003, 51, 3157-3161. [CrossRef] [PubMed]

15. Feistel, F.; Paetz, C.; Lorenz, S.; Beran, F.; Kunert, G.; Schneider, B. Idesia polycarpa (Salicaceae) leaf constituents and their toxic effect on Cerura vinula and Lymantria dispar (Lepidoptera) larvae. Phytochemistry 2017, 143, 170-179. [CrossRef] [PubMed]

16. Chen, J.; Mangelinckx, S.; Ma, L.; Wang, Z.; Li, W.; De Kimpe, N. Caffeoylquinic acid derivatives isolated from the aerial parts of Gynura divaricata and their yeast $\alpha$-glucosidase and PTP1B inhibitory activity. Fitoterapia 2014, 99, 1-6. [CrossRef] [PubMed]

17. Ding, H.X.; Chen, Y.J.; Zhao, J.; Song, Q.Y.; Gao, K. Chemical constituents from the aerial parts of Triosteum pinnatifidum. Chem. Nat. Compd. 2013, 49, 95-96. [CrossRef]

18. Wang, A.X.; Zhang, Q.; Jia, Z.J. Phenylpropanosids, lignans and other constituents from Cremanthodium ellisii. Pharmazie 2005, 36, 889-892. [CrossRef] 
19. Wang, G.K.; Bin Lin, B.; Rao, R.; Zhu, K.; Qin, X.Y.; Xie, G.Y.; Qin, M. A new lignan with anti-HBV activity from the roots of Bombax ceiba. Nat. Prod. Res. 2013, 27, 1348-1352. [CrossRef]

20. Chen, J.J.; Fang, H.Y.; Duh, C.Y.; Chen, I.S. New indolopyridoquinazoline, benzo[c]phenanthridines and cytotoxic constituents from Zanthoxylum integrifoliolum. Planta Medica 2005, 71, 470-475. [CrossRef]

21. Achanta, S.; Liautard, V.; Paugh, R.; Organ, M.G. The development of a general strategy for the synthesis of tyramine-based natural products by using continuous flow techniques. Chem. Eur. J. 2010, 16, 12797-12800. [CrossRef]

22. Hsieh, T.J.; Chang, F.R.; Chia, Y.C.; Chen, C.Y.; Chiu, H.F.; Wu, Y.C. Cytotoxic constituents of the fruits of Cananga odorata. J. Nat. Prod. 2001, 64, 616-619. [CrossRef] [PubMed]

23. Goda, Y.; Shibuya, M.; Sankawa, U. Inhibitors of the arachidonate cascade from Allium chinense and their effect on in vitro platelet aggregation. Chem. Pharm. Bull. 1987, 35, 2668-2674. [CrossRef] [PubMed]

24. Munoz, O.; Piovano, M.; Garbarino, J.; Hellwing, V.; Breitmaier, E. Tropane alkaloids from Schizanthus litoralis. Phytochemistry 1996, 43, 709-713. [CrossRef]

25. Liao, J.; Yuan, C.; Di, Y.; He, H.; Hu, X. A new indole alkaloid from the fruits of Capparis masaikai. Asian J. Chem. 2014, 26, 4504-4506. [CrossRef]

26. Tian, S.; Yang, Y.; Liu, K.; Xiong, Z.; Xu, L.; Zhao, L. Antimicrobial metabolites from a novel halophilic actinomycete Nocardiopsis terrae YIM 90022. Nat. Prod. Res. 2013, 28, 344-346. [CrossRef] [PubMed]

27. Chang, C.L.; Zhang, L.J.; Chen, R.Y.; Kuo, L.M.Y.; Huang, J.P.; Huang, H.C.; Lee, K.H.; Wu, Y.C.; Kuo, Y.H. Antioxidant and anti-inflammatory phenylpropanoid derivatives from Calamus quiquesetinervius. J. Nat. Prod. 2010, 73, 1482-1488. [CrossRef] [PubMed]

28. Chao, C.L.; Huang, H.C.; Lin, H.C.; Chang, T.C.; Chang, W.L. Sesquiterpenes from Baizhu stimulate glucose uptake by activating AMPK and PI3K. Am. J. Chin. Med. 2016, 44, 963-979. [CrossRef]

29. Lin, Y.L.; Wang, W.Y.; Kuo, Y.H.; Chen, C.F. Nonsteroidal constituents from Solanum Incanum L. J. Chin. Chem. Soc. 2000, 47, 247-251. [CrossRef]

30. Asres, K.; Mascagni, P.; O’Neill, M.J.; Phillipson, D. Isoflavonoids from Bolusanthus speciosus (Bolus) Harms Leguminosae. Zeitschrift für Naturforschung C 1985, 40, 617-620. [CrossRef]

31. Von Massow, F.; Smith, M.A.R. Indirect ${ }^{13} \mathrm{C}-{ }^{1} \mathrm{H}$ coupling in asymmetrically trisubstituted benzenes: A carbon-13 nuclear magnetic resonance study. J. Chem. Soc. Perkin Trans. 2 1976, 2, 977. [CrossRef]

32. Chung, C.P.; Hsia, S.M.; Lee, M.Y.; Chen, H.J.; Cheng, F.; Chan, L.C.; Kuo, Y.H.; Lin, Y.L.; Chiang, W. Gastroprotective activities of Adlay (Coix lachryma-jobi L. var. ma-yuen Stapf) on the growth of the stomach cancer AGS cell line and indomethacin-induced gastric ulcers. J. Agric. Food Chem. 2011, 59, 6025-6033. [CrossRef] [PubMed]

33. Fraser, B.H.; Perlmutter, P.; Wijesundera, C. Practical syntheses of triacylglycerol regioisomers containing long-chain polyunsaturated fatty acids. J. Am. Oil Chem. Soc. 2006, 84, 11-21. [CrossRef]

34. Li, Y.H.; Lai, C.Y.; Su, M.C.; Cheng, J.C.; Chang, Y.S. Antiviral activity of Portulaca oleracea L. against influenza A viruses. J. Ethnopharmacol. 2019, 241, 112013. [CrossRef] [PubMed]

Sample Availability: Samples of the compounds 1, 8, 10, 11, 16, 17, 22, 26-30 are available from the authors.

(C) 2020 by the authors. Licensee MDPI, Basel, Switzerland. This article is an open access article distributed under the terms and conditions of the Creative Commons Attribution (CC BY) license (http://creativecommons.org/licenses/by/4.0/). 